\title{
The Community Relationships of an Industrial Plant
}

\author{
By J. C. Heckman
}

Consulting Engineer, Larkin Company, Buffalo, N. Y.

WHILE a general appreciation of the fact has been slow in reaching many industrial managers, it is scarcely open to argument that one of the greatest, if not the greatest, assets of any industry is a personnel of thoroughly contented employes. It is perhaps not quite so well appreciated even by the more progressive employer, how vitally the contentment of his employes is influenced by their environment outside of working hours.

Much time and thought have very properly been devoted in recent years to improving working conditions in manufacturing plants. Not nearly so much attention has been given to the conditions surrounding the employe outside of the plant.

An employe of a manufacturing plant, working eight hours a day and losing no time from sickness or other causes, spends approximately $27 \frac{1}{2}$ per cent of his time in the factory; the other $72 \frac{1}{2}$ per cent is spent outside. The manner in which this major portion of the employe's time is spent and the influences exerted upon him by his environment, are of overwhelming importance in determining the character of the employe and his value to the industry. The effect of the nature of a community upon the welfare of its industries, therefore, can scarcely be exaggerated.

A manufacturer having his plant already built has no opportunity to select a community presenting the most favorable conditions for his employes. In order to get the best conditions, he is restricted to the slow and difficult process of influencing the progress of a community along desirable lines. The manufacturer, however, who is about to select a location for a new plant, has before him the opportunity of making a selection which will provide his employes with the best possible conditions under which to live. The opportunity is too valuable to be lightly dismissed.

There are notable instances in which an industry has been located outside of an existing community and has created a new 
community adjacent to its plant. In some cases, economic manufacturing conditions compelled the location of the plant in an unsettled region, but in others such a location was deliberately chosen in order that the industry might create its own community and control its character.

There is room for wide difference of opinion as to the wisdom of attempting to create a manufacturing plant, and, coincidently, an industrial community around it. There is room for still greater difference of opinion as to the wisdom, or lack of it, displayed in the developments of some of the communities already in existence. Such enterprises are only possible in connection with very large plants and under exceptional circumstances. As they are not possible for the average manufacturer, they are rather outside the scope of this discussion. The instances where an industry has deliberately elected to create a community in the interests of its employes illustrate the importance of community relationship in the eyes of some managers.

In order to view broadly the entire subject of the relations between an industry and its surrounding community, it is necessary to review the elements in the community which materially affect or are affected by an industry located in its midst. As has already been pointed out, these influences are principally effective through the personnel of the industry and they will be first considered in this connection.

\section{The Номе}

The most important factor in the life of an industrial worker is his home, and perhaps the greatest influence that a community can exercise on an industry lies in the opportunities which it offers to its personnel to provide themselves not only with comfortable and sanitary but also attractive and beautiful homes. Nothing so stimulates a man's self-respect as a home in which he can take pride. It is particularly desirable that this home be a detached or semi-detached house and that the premises include space for a small flower or vegetable garden. Such a garden is a great inducement to the tenant to occupy his leisure sanely and in a manner which conserves and builds up rather than dissipates his energies.

The most stable and satisfactory workers to any industry are those who own their own homes. This fact has been so clearly 
evident that many industries provide plans under which their employes may acquire homes on easy terms. A very large percentage of the workers, of course, will not own homes and the growth of the home owning group will be slow, although it can by proper encouragement be made steady. The availability, character and prices of suitable rented homes will, therefore, be the major factor in the home supply situation.

The home supply value of a community can be briefly summarized to be made up of the following factors : character and extent of residential districts and their relative location to the plant; transportation facilities between these districts and the plant; values of real estate and cost of building; supply of homes for rent and rent costs; building loan associations and other facilities for acquiring homes on easy payment plans; the public health record of the community.

\section{ReCREation}

Possibly the next important factor affecting the contentment of employes is the opportunities which the community offers for recreation. Of these facilities, public parks are, perhaps, the most far-reaching. Not only should there be a well organized system of public parks within easy transportation distance of all portions of the community, but the administration of these parks should energetically endeavor to make them serve the public in the broadest possible manner. There is a growing appreciation in this country of the possibilities to the public of properly administrated park systems, particularly along the lines of publicly directed games and athletics for the public in general. The ideal community would be one which is keeping well to the front in such movements. Included in the public park system, of course, should be the children's playgrounds, well distributed through the city and supervised by play directors, and public bathing beaches with bath houses when water-front facilities are available.

In addition to the public parks, the presence and character of the privately managed amusement parks have an influence. If these are of the proper character, they are an asset. Too frequently, however, they must be classed on the other side of the ledger when considered in connection with the benefits which the employes obtain from patronizing them. A popular and well 
patronized baseball team is a most excellent thing for providing recreation and stimulating civic pride. In addition to the outdoor amusements, the question of theatres, moving-picture houses, etc., deserves more than passing attention. Many communities provide municipally owned auditoriums available for large public mass meetings, concerts, lectures, etc. These must be considered also as a distinct asset.

\section{Education}

Another important side of the community is the educational facilities which it offers. Nearly every worker of the desirable sort is anxious that his children shall receive better educational advantages than his parents had. Such people are vitally interested in public school systems, and the ability of the plant to obtain the best type of workmen is often greatly affected by the character of the public schools which the community can offer such workmen's children. These schools properly conducted become the training areas for the next generation of workers. American manufacturers are appreciating how woefully they have neglected their opportunities as well as their duties in this connection. In addition to the regular public day schools, the question of night schools and continuation schools for younger employes who are already at work and the schools for teaching English and American ideals to foreign employes should also be considered. Public libraries, public museums of art and natural history, free educational lectures and concerts are also important as offering facilities for ambitious employes to continue and improve their education.

\section{Adequate Public Service}

The character of what may be broadly included in the term "Public Utilities" has tremendous influence affecting the contentment of the employes. We are hearing much these days on the subject of such public utilities, as street car service, electric light and power, telephones, gas and water service. The effect of all of these on the lives of every dweller in the community is felt daily and it is important that these utilities in the community should render good service at reasonable prices.

In addition to these enterprises, we may include in the term, many other institutions which serve the public generally and add 
or detract so much to the citizen's joy of living. For illustration may be mentioned the retail stores and their prices, markets, savings banks, hospitals, newspapers, etc. Certain cities are noted for their retail stores and superior shopping facilities; while others are famous for their markets and abundance of cheap and excellent produce. The manufacturer is fortunate who conducts a plant in a community that can offer a low cost of living.

\section{The Church}

It is, perhaps, a matter for concern that we are apt to give little consideration to the influence of the church on the industrial worker and through him on his industry. It will be admitted that the influence is not so pronounced as it might be. Nevertheless, it is there and a sane, steadying, helpful influence it is generally found to be. The churches as a factor in the community should not be overlooked.

\section{City Government}

The happiness of a citizen is, of course, affected by the nature of the government under which he lives. We have a variety of types of city government in this country. The type is more or less immaterial if the government is conducted broadly in the interests of the citizens. On one side of the ledger are the taxes collected from the people; on the other, the services rendered in return for the taxes. There is an ever widening field of activities opening out before our communities into which the citizens may enter in common through their city government. The ideal government is one under which not only are the accepted activities comprised by the departments of education, finance, public works, health, police and fire, parks, etc., being efficiently directed, but also one which, with a watchful eye on the city finances and a thorough weighing of the cost, is intelligently reaching out into fresh fields of community activities.

That community is fortunate in which the local politics have been divorced from national party politics and local policies are viewed in the light of local issues only. Under these conditions, the citizen is encouraged to take an interest in his local government by the presentation of its questions unclouded by extraneous issues and a better government and a better citizen result. 


\section{Crvic SpIRIT}

Closely allied to these matters is that imponderable quality known as civic spirit. Difficult to define, its presence is instantly recognized in the atmosphere of a really alive community. Many cities have a distinct universally recognized character all their own and if that character is good, it is perhaps that city's greatest asset. This civic spirit is frequently expressed in patriotic celebrations, community singing and Christmas trees, neighborhood street dances, pageants, support of local baseball and other athletic teams. In a more substantial way it is evidenced in the existence of and support given to associations striving for better government, for increased educational opportunities, charitable organizations, patriotic organizations, concerted efforts toward city planning and the development of the æsthetic side of the community.

Man is so constituted that he is happiest when striving earnestly in an altruistic endeavor. The citizen who takes a pride in his community, the citizen who is working for the improvement of some feature of that community, be it in ever so minor a capacity, is a better citizen and a better employe. A community that inspires to such endeavors is a good community in which to establish an industry.

\section{Labor Legislation}

The state government too has its influence on the contentment of an employe. It touches him on many sides: its taxes, its public improvements, its educational policies, its courts, its hospitals and charitable institutions, its political activities. Its most direct influence on the industrial worker, however, comes through its labor legislation and its labor department. There has been great activity along the lines of state labor legislation in the last decade. Much of it, the most reactionary employer must now recognize as sane and beneficial to all concerned. Unfortunately, under competitive conditions, the progressive manufacturer cannot go ahead in his measures for the well being of his working associates much more rapidly than his less progressive neighbor. Labor laws to establish certain minimum conditions of safety and sanitation and to provide prompt and adequate compensa- 
tion for industrial injuries, etc., with which all must comply, are necessary and have proved to be a distinct boon to workers.

Unfortunately too, a certain well meaning but not quite clear thinking element in our body politic has discovered the immense potential power in labor legislation for utilizing the easily reached, stable, efficient, financially responsible industrial organizations in exploiting its theories of social regeneration. Therein lies a danger and industrial safety can only be maintained by preserving a happy distinction between sound progress and irresponsible experimentation.

In considering the influence of the state upon its industries, therefore, thought should not only be given to its existing industrial code, but also to the recent history of its legislation and the character and strength of the influences at work urging and opposing these measures.

\section{Elements Affecting Industrial Finances and Operation}

Thus far, we have considered the community influence on an industry as it reaches it through its personnel. Other sides of the business, notably the financial and operating sides, are likewise involved in the reaction.

Before the plant is in operation, the financial side is affected by the price of suitably located industrial properties and the cost of building in the community. Overhead costs are then established that will endure as long as the plant. Other overheads created or affected by the community are taxes (real estate, personal property, income, corporation, franchise, etc.), insurance (affected by the efficiency of the local fire department and water supply), watchmen's service (affected by the character of the people living near the plant and the adequacy of the local police), cartage (affected by the character of the highways), water supply, cost of sewage disposal, etc. The banking facilities of the community are, of course, of major importance to the financial side of the industry. Freight service is, perhaps, the most important local factor affecting the operation of an industry, but express service, mails, telegraph and telephone service also have direct bearing.

Even the climate of a location has an influence not to be overlooked. This factor is almost a determining one in some special industries, but in all industries a long, cold winter means expensive 
heating plants, a snowy region means transportation troubles and extra costs, and a long, hot season cuts down the attendance and efficiency of the workers.

So complex and inter-related are the various factors that enter into the relations between an industry and its surrounding community that it is difficult to gain a comprehensive view that will include them all. We know few things absolutely, most of our knowledge is gained by comparison. A manufacturer looking for a site for a new plant compares the advantages and disadvantages offered by different possible locations. A manufacturer already located seeks to compare his community with other communities in order to ascertain the strength and weaknesses of his own location so that he can take advantage of the former and strive to correct the latter.

\section{Plan for Rating Essential Factors of Communities}

It is difficult to evaluate numerically more or less imponderable values and still more difficult to weight properly such values so that each may have its proper degree of predominence in the whole. Nevertheless, even an admittedly crude and inaccurate means of measurement is better than none and, if applied with a full knowledge of its limitations, will yield results of value.

An attempt has been made in the succeeding scheme to present a method for rating the essential factors of communities as affecting an industry and for tabulating these ratings so that their totals for the communities may represent the relative values of these communities as locations for industrial establishments.

It is desired to emphasize the point that the factors listed in this table and the weighting given each are purely suggestive and may well be modified in accordance with the judgment of the investigator to fit a specific study.

A study based on such a rating plan might be found fruitful of suggesting by a Chamber of Commerce or similar body in determining the value of its community as an industrial center.

It will be noted that the factors of a community affecting industry are grouped under eight headings. In the first column opposite these headings is given the maximum weighted value for each group and the maximum weighted value assigned each sub factor in the group, the total of which equals the value for the group. 
The second column is headed "Present Value." In this column, the investigator is to note his estimate of the value of each factor in the community under consideration. For obtaining these values, it is suggested that for each item in the list, the observer prepare a scale using for the maximum, not the ideal community, but the community familiar to him which stands highest in that particular quality. Similarly, the poorest community in that quality known to him should be rated zero. It will then be fairly easy to place the community under consideration on the scale. If the observer can place a third community on the scale about half way between the best and poorest, it will assist materially in correctly placing others.

The third column is headed "Future Value." This column is added to aid particularly in the consideration of a small community where few of the factors mentioned now exist. It is proper in judging the possibilities of such a place for the establishment of a new plant to estimate the probable development of the community after the plant is established. This column is particularly advantageous for comparing the desirability of large and small communities.

A city has the great advantage of being a going concern with all, or nearly all, of the activities shown already in full operation. It has the disadvantage that the going is not all in a desirable direction and one industry will have comparatively little influence in steering it. In the small community, however, although few of the desired activities are started, a new industry has the opportunity of assisting in starting these activities and a very large influence in directing their progress. The results attained, however, will only be in proportion to the serious thought and effort which the industry is prepared to devote to this work.

Taking all these things into consideration and entering in the third column a fair estimate of the value of each factor at a period, say five years in the future, the results will furnish a much fairer basis for comparison than the present day figures. 


\section{RATING TABLE FOR ESTIMATING COMPARATIVE INDUSTRIAL CENTER VALUES OF COMMUNITIES}

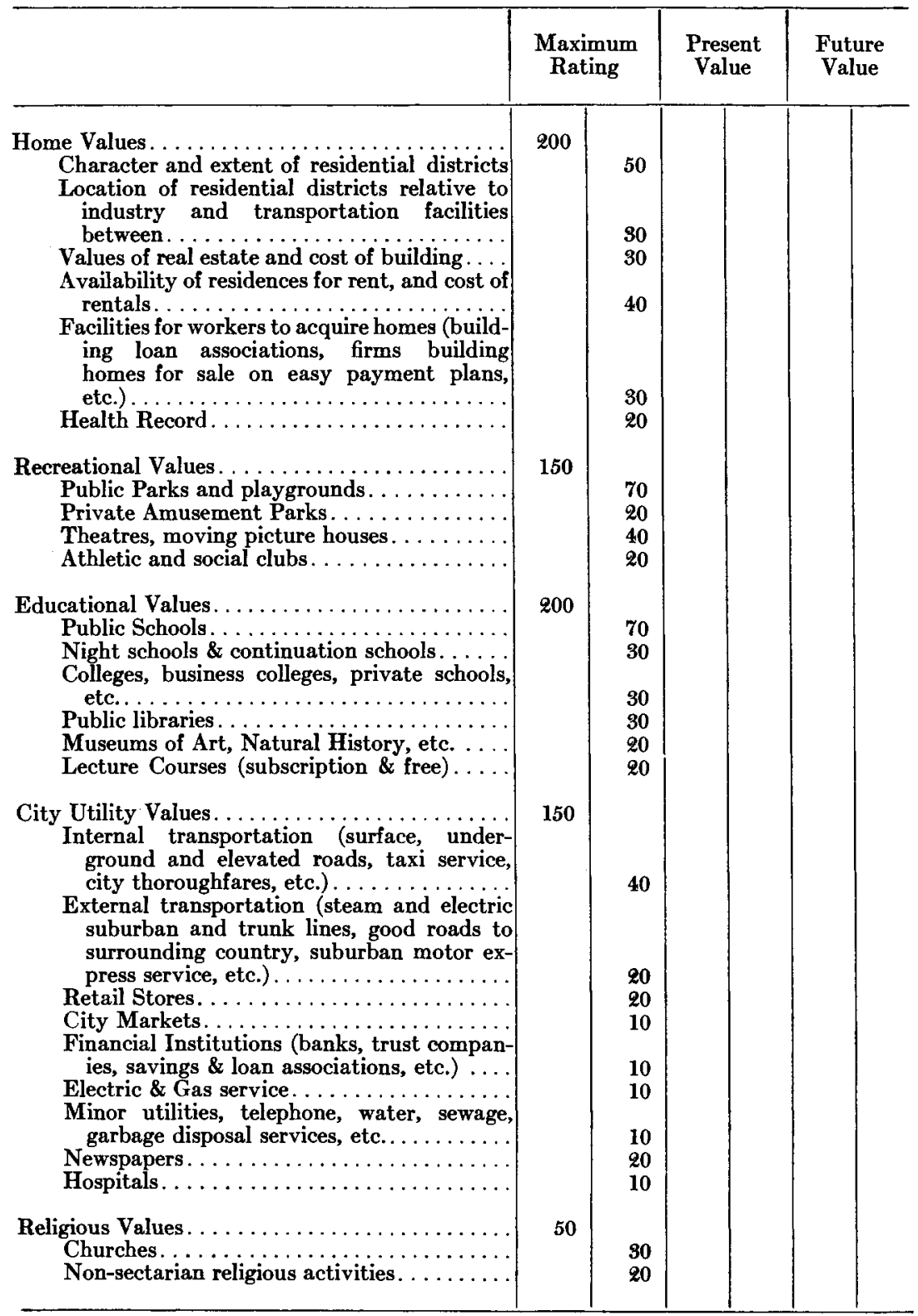


RATING TABLE FOR ESTIMATING COMPARATIVE INDUSTRIAL CENTER VALUES OF COMMUNITIES-Concluded

\begin{tabular}{|c|c|c|c|c|}
\hline & \multicolumn{2}{|c|}{$\underset{\text { Rating }}{\text { Maximum }}$} & $\begin{array}{c}\text { Present } \\
\text { Value }\end{array}$ & $\begin{array}{l}\text { Future } \\
\text { Value }\end{array}$ \\
\hline 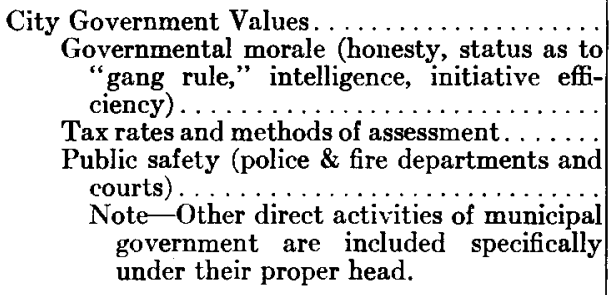 & 100 & $\begin{array}{l}50 \\
30 \\
20\end{array}$ & & \\
\hline 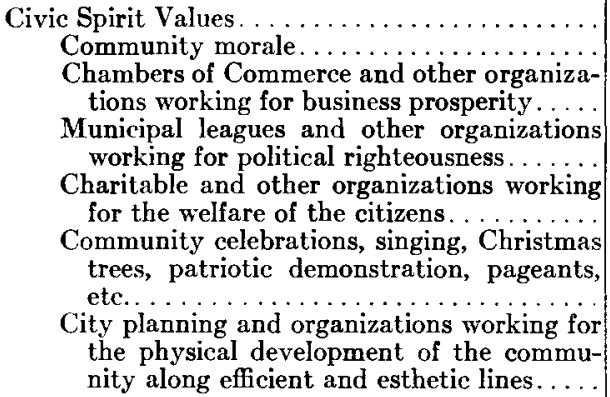 & 100 & $\begin{array}{l}10 \\
10 \\
10\end{array}$ & & \\
\hline 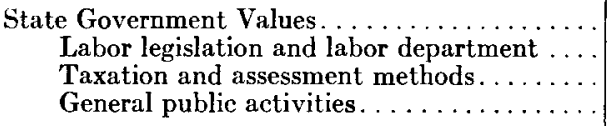 & 50 & $\begin{array}{l}30 \\
10 \\
10\end{array}$ & & \\
\hline Totals. . & 1,000 & 1,000 & & \\
\hline
\end{tabular}

\section{Responsibility of the Industry to the Community}

Thus far we have only considered one side of the situation: how does a community influence its industries, what can or should it give them? Equally important is the other side of that picture: how does an industry influence a community and what can or should it give it?

Again the personnel element looms up as the most important. The industry's most profound influence on a community is exercised through the workers which it gathers together and makes dwellers in the community. If the community is to be prosperous, its industries must be prosperous and equitably share their prosperity with their workers. If the community is to be healthy, 
the working conditions in its industries must be sanitary. If the community is to be happy, the industrial relations of its industries must be most wisely and liberally administered.

On the other hand, it is fatal for an industry to attempt to prescribe the daily life of its workers in the community and outside of the factory. Benevolent paternalism, however wellwishing, is un-American and does not prosper on our soil. The American workman jealously guards his privilege of making his own mistakes and learning how to live by his own hard knocks. The management of an industry can and should do much to create amongst the employes a desire for higher and wiser standards of living; to point out ways and means for advancing towards these new standards and even to assist most carefully in this progress. But such efforts always require the most tactful handling. Never should the management permit itself to assume an air of superior mental or moral elevation; never should the employe be permitted to feel for an instant that he has sacrificed one iota of his free will or that he is doing anything for any other reason than that he deliberately wants to do it. The management's part is to create or stimulate the desire and later most unobtrusively to supply the means for its fulfillment.

But aside from its relations to the community through its personnel, the industry will find it good business for its management to enter most heartily into the commercial life of the community. It is a fundamental principle of democracy that united, as a community or a state or a nation, we can achieve results impossible to us as individuals. And so an association of the industrial representatives of a community can accomplish beneficial results for its industries as a whole and for the community, which would be impossible to any one of these alone. Such subjects as honest and efficient municipal government, fair tax laws, wise and equitable labor legislation, adequate service from public service corporations, uniform conditions of labor in the community, adequate banking service, the industrial development of the community, public health, housing, Americanization of aliens, etc., are all subjects to which the business men of a community may well devote their organized attention.

It is not questioned that an active, aggressive chamber of commerce or board of trade or similar organization of the commercial 
interest of a community is a benefit to the community, and such an organization is active and aggressive just in proportion to the amount of time and energy that its members put into it. An industry has but a narrow conception of its own best interests which does not devote a considerable portion of its energies to such associated work. But the wise industry will exercise care that the organizations it is active in are guarded against short sighted, selfish policies. It is particularly necessary that public bodies of this nature heed the paradoxical truth that unselfishness is the wisest kind of selfishness.

The industry located in a small community where few or no other industries exist and commercial organizations such as those mentioned are not possible, finds itself confronted with a great opportunity and a great responsibility. On it very largely rests the character and extent of its community's development. It must supply the place not only of such a commercial body but also of many other organizations devoted to the public weal existing in the larger towns and cities. It must be prepared, therefore, to give even more of its time and effort to public service than its city compeer. Unless an industry is prepared to assume this privilege and this duty, it would be wiser for it to locate in a large community.

The modern industry must consider its community relationship as one of the vital factors in the conduct of its business. It must realize that it extends beyond the four walls of its factory building into the remotest corners of the community and that to achieve the highest success, it must gain a broad comprehension of its community and, with a nice sense of their relative importance, enter into all of its activities. 